\title{
The Heart of Learning
}

\author{
Allan M. MacKinnon \\ Simon Fraser University, Burnaby, Canada \\ Email: Allan_MacKinnon@sfu.ca
}

Received October $17^{\text {th }}, 2013$; revised November $17^{\text {th }}, 2013$; accepted November $24^{\text {th }}, 2013$

Copyright $(2) 2013$ Allan M. MacKinnon. This is an open access article distributed under the Creative Commons Attribution License, which permits unrestricted use, distribution, and reproduction in any medium, provided the original work is properly cited. In accordance of the Creative Commons Attribution License all Copyrights (C) 2013 are reserved for SCIRP and the owner of the intellectual property Allan M. MacKinnon. All Copyright $\mathbb{C}$ 2013 are guarded by law and by SCIRP as a guardian.

\begin{abstract}
This essay explores the central importance of human interest and aspiration in learning. In an age when our educational institutions and ministries of education seem to be preoccupied with defining and measuring the "outcomes" of schooling, there is a great need to reconsider what we are doing in curriculum studies and refocus at least some of our energy on helping young people develop and sustain their interests. I use an autobiographical account of my interest in playing guitar and how this is related to my formative school experiences to develop my argument. The article also reviews literature tracing educational research and writing that focuses on the role of interest in learning.
\end{abstract}

Keywords: Motivation; Curriculum Studies; Activity Theory; Student-Centered; Learning Theory

\section{Introduction}

There is something about human character and spirit that lies at the heart of learning, an emotive aspect of human nature and development that brings one to put one's heart into something, or to have one's heart set on something. The heart (core, center) of the matter is the heart (passion) of learning, that is, the emotive qualities associated with intrinsic motivation that make us who we are. So the title of this essay is a pun with its double meaning, the heart of learning. What I do not mean by the heart of learning is "learning by heart"-our familiar colloquialism for memorizing something - unless of course we are talking about someone who memorizes, say, Marc Anthony's funeral speech from Julius Caesar to satiate a passion or obsession for Shakespeare. Actually, I am writing about the role of human interest in learning and what I wish to say is - the heart of learning is human interest.

We need a deep personal construct psychology, or a theory of being that would give new life to our understanding of learning, knowledge and cognition by placing these concepts firmly in a context of human agency vis-à-vis interest and aspiration. It is the interests and aspirations of learners that determine the relationship they will have with whatever curriculum they encounter, whether in school or elsewhere. It is in the interest of learners that we should think again about what motivates learning, how learners become motivated, and what sustains their motivation. This essay is not so much a report of a research study as it is a call to the educational research community, particularly in the area of curriculum studies, to reconsider fundamental notions about schooling and education. I explore my own story, my own experience in the formative years at school that shapes me and influences the way I am in the world to this day-the way I see and understand the world, the way I see and understand myself, and therefore how I find my place in the world.

\section{The Challenge for Curriculum Studies}

Suppose we were to heighten our awareness of the role of human interest and aspiration in learning in order that we might develop a different kind of window for looking out at the educational world? What would a school system or a ministry of education look like, for instance, if it were built more upon the interests of learners, and less upon what we expect them to learn? What curriculum would we draw upon? Whose "curriculum"? Surely we would ultimately have to turn the concept of curriculum on its head such that the central driving force would be the interests of learners rather than those of ministries of education and political influences.

\section{Learning as Purposive Activity}

Let us consider first what goes into learning and then search for a literature that illuminates the concept of human interest and its role in learning. Learning is a purposive activity-it is willful, deliberate and intentional, and it is manifest in a person's activity, behavior, outlook-in short, his or her way of being in the world (Engeström, 1987, 1999; Lave \& Wenger, 1991). This means that learning comes to bear in the context of an agenda, that is, it happens when someone strives to achieve, when somebody 'reaches' for something. As learning is purposive, we cannot receive an education; we must take an education. In order to flesh out and illustrate what this means, I develop here an autobiographical account of my own life-long interest in playing guitar. This interest is at the heart of my own learning and development, my own identity I would say.

\section{The Concept of Interest}

I believe the typical attitude of educators toward students' interests is one of casual indifference. By this I mean that many 
of us actually believe we can educate children along side their interests at best, or worse, despite their interests. I think this is unfortunate; I believe that students' interest is by far the single most important ingredient of their education. In search for a deeper appreciation of the concept of interest and its role in learning, it is useful to review a brief history of the development of the concept as an important construct in the field of education.

Herbart $(1806 / 1965 a, 1941 / 1965 b)$ is cited as the first psychologist to recognize the role of interest in learning (Hidi, 1990; Schiefel, 1991). He theorized that interest allows for complete and accurate recognition of an object, that it leads to meaningful learning and long-term storage of knowledge, and it stimulates further learning. Schiefel (1991) notes that this early work in psychology took hold in the work of a few German psychologists, including Kerschensteiner (1922) and Lunk (1926, 1927). Dewey $(1913,1916,1938)$ is often cited as the first 'modern day' psychologist/philosopher to write about the role of interest in learning and education (Hidi, 1990; Schiefel, 1991). Hidi (1990) provides an extensive review of more recent research and writing in this area, but comments as well on the paucity of attention to the role of interest in learning.

Once we accept the premise that individual interest facilitates learning, we must consider how interest develops, how the interest/learning relationship actually works, and how it could best be utilized in schools. ... In fact, it is remarkable how little we know about how early interests begin and what they lead to. (p. 553)

\section{My Story}

As a young boy I became intrigued with guitars at the age of six or seven. It was 1961, a time of innovation and creation in the early years of the electric guitar and I was consumed with the looks and the sounds-the whole ethos and intrigue surrounding the guitar. When I was in grade three I made a guitar from cardboard with elastic strings, and on seeing this, my mother bought me a ukulele. I learned to play and sing songs like 'Old Black Joe,' which I performed for my class at the grade four Christmas party. I began to notice the relationship between lyrics and musical tones and passages, as well as the way an audience interacted with them. This first public performance of strumming and singing was a milestone for me, and I remembered it as such for many years to come.

The school in which I was enrolled had a school-wide assembly every Friday morning-a practice that continued throughout my attendance at the school from grade one to six. At one of these assemblies when I was in Grade Two, an older student mesmerized me by singing and playing electric guitar to 'Sugar Time.' Later, when I was in Grades Five and Six, I was given extra jobs as a student monitor around the school for various weekly routines. The assembly was one of these routines; for this I was in charge of operating the public address system and stage lighting in the school auditorium. In this role I also prepared the children who were about to perform in front of their peers. The performance could be a dance, a piece on the piano or violin, a song, a poem or short story that was read. A sense of show business enshrouded me as though I were the host of a variety show in the early days of television. Still prominent in this whole gestalt, even today, is the memory of the older boy singing, 'Sugar in the morning, sugar in the evening....'
By grade six I had my first guitar and this was very significant in my long journey of self-discovery. I also absorbed a sense of show business vis-à-vis the school assembly, as I had the experience of helping many of my school mates step in and out of the spotlight on the school stage. By the time I was in high school I was known to be a good guitar player, partly of course because I also seemed to know how to work the stage.

I began playing with rock and country rock bands at the age of fourteen; about the same time I began to teach guitar for a local music conservatory. The guitar led me further and further into other worlds, as I became fascinated with teaching the guitar, how kids learn the guitar, how many different ways one can play the guitar, 'put one's finger prints on it.' I noticed among my young students that only those who really wanted to play would play proficiently, that those who struggled also seemed to lack interest and motivation. To those who are passionate about guitar, playing it comes easily.

I continued to teach guitar while attending university and eventually I became a school teacher and later a professor of education. The whole while I continued to play guitar as much as I could, continued to perform with bands, continued to write and record music, still with the guitar as large as ever in my mind. I still think, from time to time, about the older boy at the school assembly singing 'Sugar Time,' and the feeling of prepping my fellow classmates for the stage and ensuring the sound and lighting were working properly. Not only am I still passionate about guitars to this day, I see myself as a guitar player just as I did back in elementary school.

\section{Sustained Interest}

What can we say about this guitar in a young boy's mind? And what of the relationship between the boy and the guitar? My interest in the guitar certainly had its influence on my learning and development. It is one of my 'inputs' of learning, one of the 'resources' for my education. One might say this is obvious; why single it out? Out of all of the things I would learn about and all of the many and varied activities in my life, why focus on a childhood interest? Wouldn't an education lead a person away from childhood interests, further and further from them, rather than deeper and deeper into them?

What can be said about a boy and a guitar? I learn about myself through my engagement with the guitar and this provides the foundation for much of my other learning because this is how I know myself. This view of myself in the world lies at the core of my education and development, my engagement. My view of myself as a guitar player influences my academic and teaching life, the way I interact with students and colleagues. I am a guitar player first, then a husband, a father, a teacher, a colleague. I carry myself as a guitar player, I go where guitar players go. I speak like a guitar player, act like one. I am living out my conception of myself in the world, at the very base of which lies my childhood passion, ever evolving, one I have lived out all of my life. It is the guitar that will bring me out into the world, help me to stand tall at my horizon to look out at my future and see opportunity.

\section{Individuality and Opportunity in Learning}

Why guitar? Why not baseball? What made my interest so strong, so alive? What seed was planted in my mind and how did this occur? Here we can theorize until we are blue in the 
face, still how interest develops must surely remain a mystery, something like a miracle that happens somehow through our interactions with our families, heritage, culture, and the various situations in which we find ourselves. How interest happens is illusive, yet we cannot deny the over-arching influence of our passions and desires over what we become.

Having said that, we may consider another input of learning as opportunity - opportunities in life to develop and pursue interests and passions. These are the formative times in our lives when we have the opportunity to develop interests in the first place. Of course this depends on milieu, culture, economic condition, the fashion of the times, and so on. Nevertheless, we could in my example come to see the guitar as a tool and means with which I interact with the milieu. The guitar not only mediates my engagement in the world, it allows for the engagement in the first place. In this way we begin to understand the guitar and a young boy's interest as ingredients of learning. Through the guitar, I interact with the world. My passion for the guitar develops and presents me to the world dialogically through the opportunities at hand.

The opportunities at hand nourish our view of ourselves and our deepening passions and forming identities. The more I became known for playing the guitar, the more opportunities came and the more I was occupied - preoccupied - with playing the guitar, and the more I put my heart into it. We can begin to see the individual's relationship with society - the opportunities at hand - as karaoke. Literally, the word means 'empty song.' In karaoke, one can enter an empty song and fill it as its singer. The technology of karaoke provides a musical structure that is quite literally a song without a singer. Through karaoke, people find out whether they are singers or not. The more they feel like singers, the more they go to karaoke; the more they go, the better they get and the better the response from the audience; the better the response, the greater they feel and behave like a singer, and so on in spirals of contingencies. The occasion to 'enter the song' is furnished by the individual's developing identity, which is in dialogical relationship with society.

When we think about a child's developing identity, we can see in my example that the guitar is at the center of a whole world of influences. The very nature of rock and roll music provides a template for social uprising and critique. It is a culture of rebellion, and the guitar especially is like a tool for the working-class man to sing the blues, to express his opinion about the way things are and the way they ought to be. The guitar, together with the culture of rock and roll music, can become a vehicle for transcending from the conditions of everyday life and the problems of society. In this sense, the guitar is like the pen of the poet, which permits a certain element of cheekiness and impertinence on the part of rock and roll musicians, and hence some latitude for a young boy in expressing himself as I did.

I suppose I would need a great deal more thought and analysis in order to truly understand the role of the guitar in my mind and heart and my learning. Of course, I was not alone in my interests and motivations. There were and still are many, many other people of all ages like myself who have a guitar stuck in their minds, who anchor themselves in life with a guitar. We would need to learn a great deal more to understand why this is the case. But it is fascinating to think, in the example developed here, that I was in fact profoundly influenced by my early school experience, particularly my formative elementary school days. As I look back on my early school experiences, these profound influences seem to have had little to do with the curriculum, or the intended outcomes of the school system in terms of the way we understand them today.

\section{A Theoretical Foundation for Interest}

We cannot appreciate the importance and role of the guitar in a child's mind and education without turning to some kind of personal construct theory or psychology. We need a dialogical view of self and its social contingencies that is developmental and multi-focal (Jonassen, 2000; Wertsch, 1998, 1991). We also need a conception of education as an emotive process that, for better or worse, follows in the wake of human interest, aspiration and identity. The core of education for me is the question of how one comes to know oneself. How do we, as social entities, compose ourselves? How do we understand what and who our influences are, and how is it that we come to see ourselves in relation to these influences? Our interests tend to define us as well as our socio-cultural contingencies in the world; they play a vital role in the kind of education we will ultimately take for ourselves.

\section{Activity Theory and Dialogism}

Knowledge is always embedded in some kind of exchange, some kind of relation, either mental or material (Lave \& Wenger, 1991; Wertsch, 1991). By material, I'm referring to the body and its physical constituents and circumstance, drawing attention to the notion that our knowledge is not only in our minds, but also embedded in our movements, actions, activities, mediated social practices and rituals (Jonassen, 2000; Lave \& Wenger, 1991). Part of our knowledge we also need to see as being unmitigated, that is it grows inside our minds and bodies without our being aware that it's there. It turns out that some of our learning is not intentional, that we know more than we can tell, that we know how to do many things we are unable to describe.

Together, personal construct theory, a dialogical view of self, identity and agency, and a view of knowledge as mediated activity in social practices, provide a way to see the role and importance of interest in learning. Here, psychology, sociology and philosophy come together in a contemporary notion that illuminates the depth of interest and learning that is possible in young minds and the over-arching power that their interests wield in shaping their lives.

\section{A Promising Turn in Policy}

I think there are two main points I would like to make about learning. The first is really a comment on human nature itself. It seems as though we are under constant self-composition or selfconstruction. We make ourselves up as we go. It is as though every day brings a re-birthing of interest, a new act of reaching for the next bit of information, the next fix of playing the guitar or whatever it happens to be, as though a person is never really fully developed. What we think as our identity seems to be in flux, in constant motion, under continual assessment, as though cognition itself is the act of reaching. This is like a stage in the school auditorium during assembly. The educational point to be made is that this is the assembly where learning happens. There are many people in the wings, in our various individual assemblies, of course, but the second point about learning - the one 


\section{A. M. MACKINNON}

that we just cannot seem to grasp publicly - is that each of us is really our own director, determining the program as we go. The assembly, whether it actually occurs in public or only in our minds, helps us to see ourselves in relation to, and in terms of our interests. We need some kind of reification of public interest in our school system that would bring new ways of addressing the intellectual and emotional development of our children. In short, we need to engage in our students, sometimes leading, sometimes following their interests, but always focusing on identifying, sustaining, and developing genuine interest in our classrooms.

The recent British Columbia Education Plan (BC Ministry of Education, 2011) presents a Canadian example of a radical new policy framework for the role of student interests and aspirations in their learning. A short excerpt is illustrative and provides an appropriate optimistic note with which to end this article:

Under the Plan, teachers, students and parents will work together to make sure every student's needs are met, passions are explored and goals are achieved. This means student-centered learning should be focused on the needs, strengths and aspirations of each individual young person. Students will play an active role in designing their own education and will be increasingly accountable for their own learning success. It's all about putting students at the center of education. That means giving teachers and schools the flexibility to make sure each student is well served by their educational program. Each student is unique and our education system will support each student's interests and ways of learning (p. 5).

\section{REFERENCES}

Dewey, J. (1913). Interest and effort in education. Boston: Riverside.
Dewey, J. (1916). Democracy and education: An introduction to the philosophy of education. New York: Macmillan.

Dewey, J. (1938). Experience and education. New York: Macmillan.

Engeström, Y. (1987). Learning by expanding: An activity theoretical approach to developmental research. Helsinki: Orienta-Konsultit Oy.

Engeström, Y. (1999). Activity theory as individual and social transformation. In Y. Engeström, R. Miettinen, \& R. L. Punamäki (Eds.), Perspectives on activity theory (pp. 19-38). Cambridge: Cambridge University Press. http://dx.doi.org/10.1017/CBO9780511812774.003

Herbart, J. F. (1965a). General pedagogy, derived from the goal of education. In J. F. Herbart (Ed.), Pädagogische Schriften (Vol. 2, pp. 9-155). Düsseldorf: Küpper.

Herbart, J. F. (1965b). Lectures on pedagogy. In J. F. Herbart (Ed.), Pädagogische Schriften (Vol. 3, pp. 157-300). Düsseldorf: Küpper.

Hidi, S. (1990). Interest and its contribution as a mental resource for learning. Review of Educational Research, 60, 549-571. http://dx.doi.org/10.3102/00346543060004549

Jonassen, D. H. (2000). Revisiting activity theory as a framework for designing student- centered learning environments. In D. H. Jonassen, \& S. M. Land (Eds.), Theoretical foundations of learning environments (pp. 89-121). Mahwah, NJ: Lawrence Erlbaum Associates.

Kerschensteiner, G. (1922). Theory of education. Leipzig: Teubner.

Lave, J., \& Wenger, E. (1991). Situated learning: Legitimate peripheral participation. Cambridge: Cambridge University Press. http://dx.doi.org/10.1017/CBO9780511815355

Lunk, G. (1926). Interest: Vol. 1: Historical-critical part. Leipzig: Klinkhardt.

Lunk, G. (1927). Interest: Vol. 2: Philosophical-educational part. Leipzig: Klinkhardt.

Province of British Columbia, Ministry of Education (2011). BC's Education Plan. Victoria, BC.

Schiefel, U. (1991). Interest, learning and motivation. Educational Psychologist, 26, 299-323.

Wertsch, J. V. (1998). Mind as action. New York: Oxford University Press.

Wertsch, J. V. (1991). Voices of the mid: Socio-cultural approach to mediated action. Cambridge, MS: Harvard University Press. 